\title{
EXPLORING ONLINE NEWS AS COMPARATIVE STUDY BETWEEN VENDATU AT INDIAAND RUANGGURU FROM INDONESIA IN COVID-19 PANDEMIC
}

\author{
Maichel Chinmi \\ Master Candidate, Master's Degree of Communication Science Department, Post-Graduate Studies \\ Universitas Bunda Mulia, Tangerang, Banten, Indonesia
}

\section{Dr. Rustono Farady Marta}

Head of Department, Master's Degree of Communication Science Dept., Post-Graduate Studies Universitas Bunda Mulia, North Jakarta, Jakarta, Indonesia

\section{Dr. Cosmas Gatot Haryono}

Lecturer, Communication Science Department, Faculty of Social Sciences and Humanities Universitas Bunda Mulia, North Jakarta, Jakarta, Indonesia

\section{Joshua Fernando}

Lecturer, Communication Science Department, Faculty of Communication Science Universitas Mpu Tantular, East Jakarta, Jakarta, Indonesia

\author{
Jai Kishon Goswami \\ Assistant Professor, Amity School of Communication \\ Amity University Chhattisgarh, Raipur,India
}

\begin{abstract}
To prevent the spread of COVID-19, schools are closed in India and Indonesia. Governments have to make hard decisions which result in students are having a hard time studying. They have to stay and study at home. Not all schools are ready for online school as the tools or systems are not ready. Fortunately, Vedantu and RuangGuru as education platforms based on mobile applications and computers give free access to students in times of COVID-19. Through this research the authors find many ideations come up back and forth through the process from the decision which the governments made until solutions come from the support of Vedantu and RuangGuru application. In this journal, the authors try to compare two news reported by NewIndianExpress.com and JakartaGlobe.id where the authors find three parts of news that have similar ideations and the three categories which in part of ideation (cognitive, emotional, social). To analyze the news the authors use Mayring methodology as the tools to analyze textual content and ideations as the theory to compare between the two news. There are three similarities being compared between India and Indonesia. Firstly, the governments' policy to prevent the spread COVID-19 where they want to establish beliefs, values, and self-image through cognitive categories, Secondly Decision making to close the school and start online learning which is not well-prepared as their emotional category involved to bring self-efficacy and responses, Lastly Vedantu and Ruangguru come to support and influence (Social category).
\end{abstract}

Keywords: Ideations, Mayring, Vedantu, RuangGuru, COVID-19.

\section{INTRODUCTION}

Education International organization tracks the country-wide school closures in 188 countries with 1,576,021,818 learners are impacted, and 63,000,000 are affected. The pandemic COVID-19 creates problems in the world of education, such as, students and teachers are not able to go school like it used to be, schools have to find a way out to ensure students are still able to study and teachers are also able to teach in the midst of this outbreak. While Education contributes to people's life meaning, the education system creates future 
adults who can give good contributions to their own country in the future. Thus, it is a disaster if education stops, and people are not able to study or learn any longer (Schinkel et al., 2015). This might happen now since the pandemic COVID-19, where some countries are having a hard time to go to school as most of the governments try to prevent the spread towards home quarantine (Asquith, 2020).

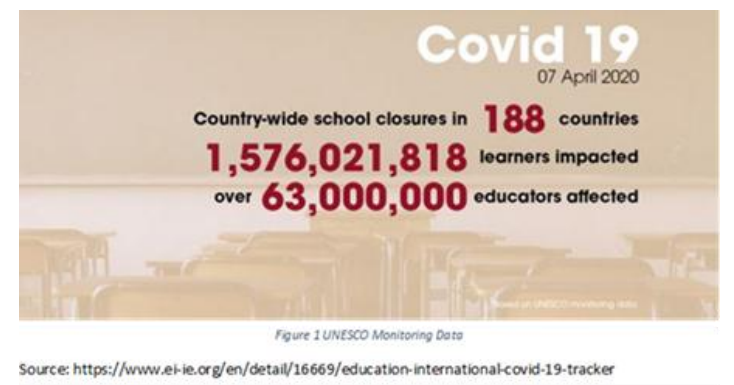

In history, there are many significant disease outbreaks and pandemics recorded, for instance, Spanish Flu, Hong Kong Flu, SARS, H7N9, Ebola, Zika. Influenza pandemics have struck three times every century since 1500 . Pandemic refers to a widespread epidemic of the contagious disease the whole of a country or one or more continents face at the same time. The term has not been defined (Qiu et al., 2017).

Schwartz et al. (2010:722) wrote about Severe Acute Respiratory Syndrome (SARS) which spread 5 continents with thousands of cases, hundreds of deaths caused by SARS. Thus people were asked to self-quarantined and restricted to travel. At the same time, online shopping had a role to fulfill the crisis. At that time online shopping contributed to preventing infection or the spread of SARS which dramatically changed consumer behavior on how they shop in the future (Forster \& Tang, 2005).

Li et al. (2014:2) also wrote about the Avian Influenza (AI) outbreak in China where the virus was derived from poultry and there was no indication on the avian when it is infected by the virus, thus, people are hard to identify. Then, social media was used in public health surveillance to facilitate interpersonal communication to share regarding monitoring on AI outbreak. It became a global phenomenon as a communication tool to disseminate disease risks and interventions and to promote a healthy lifestyle and policy in 2014 (Fung et al., 2015).

\begin{tabular}{|c|c|}
\hline Journals Title & $\begin{array}{c}\text { Authors and Years } \\
\text { Published }\end{array}$ \\
\hline $\begin{array}{c}\text { Severe Acute } \\
\text { Respiratory } \\
\text { Syndrome (SARS) - } \\
\text { Lessons for Future } \\
\text { Pandemics }\end{array}$ & Schwartz et al. 2007 \\
\hline $\begin{array}{c}\text { Preliminary Report: } \\
\text { Epidemiology of the } \\
\text { Avian Influenza A } \\
\text { (H7N9) Outbreak in } \\
\text { China }\end{array}$ & Li et al. (2014) \\
\hline $\begin{array}{c}\text { The Role of Online } \\
\text { Shopping and }\end{array}$ \\
$\begin{array}{c}\text { Fulfillment in the } \\
\text { Hong Kong SARS } \\
\text { Crisis }\end{array}$ & Forster \& Tang (2005) \\
\hline The use of social \\
media in public health \\
surveillance & Fung, Tse, and Fu \\
\hline \multicolumn{2}{|c|}{ (2015) } \\
\hline
\end{tabular}

Table 1: State of the Art

The previous studies explained during the outbreak technology became platforms which help people to prevent/stop the spread, to educate people, and to communicate. In this study during the break of COVID-19, the authors will observe how educational platforms based on technology are used to help people who are quarantined still able to study online as a revolutionary breakthrough to help the government in stopping the spread of COVID-19.

Moreover, Schools are temporarily closed in many regions in Indonesia, in an attempt to prevent the spread of COVID-19 (Nugroho, 2020). Simultaneously, many schools are also closed in India to prevent the spread of COVID-19 (NewIndianExpress.com, 2020). In other words, Indonesia and India also have the same problems in education where the world now faces.

Technological developments in the 21st century directly change people's lives (Singh, 2019). Technology capability also changes the culture of people's lives from closed to public consumption (Sachdeva \& Tripathi, 2019).

Nevertheless, Educational platforms based in technology become a trend in Indonesia and India during the outbreak. Reported by Jakarta 
Post, RuangGuru as an education application gives open access to students who are in need to study (Editor, 2020b). At the same time, NewIndianExpress.com reports Vedantu offers online learning with no cost for who is also in need to study in the times of COVID-19 (Editor, 2020c).

Through media representation, RuangGuru and Vedantu being highlighted. People are more noticed in the applications. It shows that media is a powerful tool to bring something into society or community (Govender, 2014).

This study looks at how the online media newindianexpress.com and jakartaglobe.id is raising the contribution of education application amid the COVID-19 pandemic. This study also uses qualitative content analysis as a research method and Ideation as a theory to find related issues brought by Vedantu and RuangGuru as an educational platform.

\section{LITERATURE REVIEW}

Ideation is a process to help people to develop truly original ideas in order to develop the right solution. In other words, ideation is all about brainstorming of many ideas as we can (Rgovic et al., 2013). There are two aspects which are related. They are social interaction and a new way of thinking. Ideation is all about innovation where a new way thinking are shared within a social system (Kincaid, 2015).

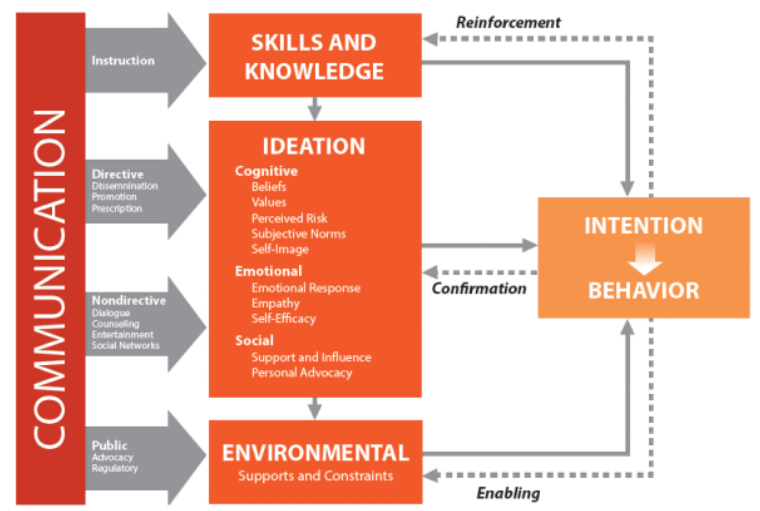

Figure 3 Ideation Process (Source: Gode, 2019)

The model (figure 3) shows that all the component affects the intermediate outcome. It determined the behavior changes. Moreover, there are three categories in ideation cognitive, emotional, and social which address different output in every category where are related to the discussion. Firstly, Cognitive is a risk perception where an individual's beliefs, values, and attitudes are addressed. Subjective norms mean what an individual perceives and what others should do. Social norms are related to what an individual thinks others are doing. Lastly, the individual thinks about himself (self-image). All the components are in the cognitive category. Second, Emotional is how an individual feels about the new behaviors either it is positive or negative and how the behavior can be performed (selfefficacy). Lastly, Social factors consist of interpersonal interaction to convince someone to behave in a certain way to adopt the new behavior when an individual can ensure someone to adopt the new behavior is called personal advocacy (Babalola et al., 2016).

Ideation can be improved when it is brainstormed. Brainstorming creates many ideas to get the synthesis to build on each other ideas rather than one person's idea. The better quality of ideation comes up when people refrained from criticizing one another's ideas. Thus, it is important to have a large number of ideas. In other words, the more ideas people generate the more good ideas will be produced (Briggs \& Reinig, 2007).

In other words, Ideation is a collaborative way of looking at social issues through putting creative ideas on the table communicating those ideas, challenging those ideas all process that leads to landing what the real question we want to ask ourselves about what the real issue is. The process makes us understand what ideation is and its focus on solution orientation (Hay et al., 2019). While the ideation's process is going through, there seem questions back and forth but they are related to the real question and what focuses on the topic. Furthermore, we never know what is right, but through ideation, we get a chance to get it right. Through ideation, it opens creativity and inspiration to get brainstorming as many as we can and grouped the ideas. So that, we can well-organized many ideas into a clear concept (Gode, 2019).

This theory fits and contributes to the topic of the field where the authors will analyze how governments' decision regarding online education creates many ideations which are related to two categories of ideation (cognitive-emotional, and social) and to see how the process creates new intention and 
new behavior of online schooling, also, Vedantu and RuangGuru as a support platform which actualizes the new behavior or intention.

\section{METHODOLOGY}

This research uses a qualitative analysis content method (Fong \& Nyathi, 2019). The object of this study consists of two news articles, representing two countries India and Indonesia. The first news article came from newindianexpress.com entitled "Education in the times of COVID-19 and how to keep up with studies" and the second news article came from jakartaglobe.id titled "Cities Turn to Online Learning to Prevent COVID-19 Spreading Among Students". This research will use the Mayring content analysis method. The mass media where the authors choose is enews. Mass media means to deliver messages or information to a large group of people where people can access anytime to receive what they are looking for (Kholik, 2015). Thus, the two news where the authors have taken, are from NewIndianExpress.com and JakartaGlobe. Id.

The two news articles through several criteria, such as an online media platform on a national scale, and exposure to international audiences, as well as continuing updates on the development of the COVID-19 pandemic in each country, were selected. The education segment was specifically chosen because it is one of the most important sectors affected, thus, encouraging all students to carry out learning activities at home using an internet service connection.

Khiang, Ahmad, Ibrahim, and Kee (2012:22) explained that framing as a way to evaluate evaluative perceptions, as it is considered by Mustaffa and Ibrahim (2018:171), the media can provide prominent information or problems on the mind of audiences. Therefore, the news becomes manipulative because it aims to dominate the subject's existence as something legal, objective, natural, and inevitable (Satriani, 2018:250).Also, (Priyo Sadono \& Fensi, 2015) describe framing as a tool to analyze a phenomenon to construct reality. Where the media has their way to deliver the news and how they stress in one particular issue with their framing (Marta et al., 2019). Categorization will be carried out before the research begins, so this study uses induction formation in qualitative content analysis. This categorization is formed from the formulation of research questions which will be followed by theoretical and conceptual frameworks.

Mayring has developed a sequential analysis of qualitative content and proposed three analytical procedures that can be carried out both independently and in combination, depending on specific research questions. The three things mentioned above (Marta \& Rieuwpassa, 2018) include abstraction, application, and structuration.

Abstraction is an attempt to reduce the material in such a way that only important content is retained. A collection of texts can be managed properly through abstractions that do not eliminate the essence of the original material. The text is paraphrased, then tries to be generalized to be abstracted and reduced. The text abstraction treatment forms a paraphrase of the message contained in newsindianexpress.com and jakartaglobe.id news content about the role of Vedantu and RuangGuru online application in the success of online learning in the general period during the COVID-19 pandemic.

Vedantu is an online tutoring platform to provide interactive online learning systems. Vedantu uses a real-time virtual learning environment named Whiteboard Audio Video Environment where students can study, browse, and discover what they want to learn. It was founded in 2011 by Vamsi Krishna, Pulkit Jain, Saurabh Saxena, and Anand Prakash. Vedantu itself means Veda: 'knowledge' Tantu: Network, thus, the founders hope a knowledge network where any student can tap into a teacher directly and learning can happen in a personalized way, anytime-anywhere

(Source: Vedantu.com/v/about-us).

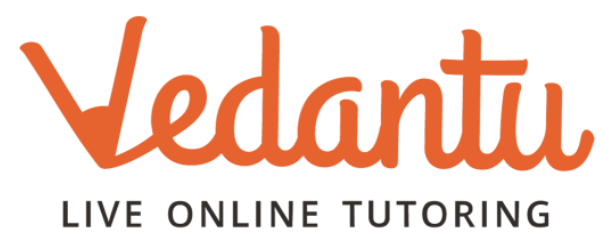

Figure 4 Vedantu Logo

Source: https://www.vedantu.com/v/about-us 
RuangGuru was founded by Adamas Belva Syah and Muhammad Iman Usman 2014. RuangGuru provides various tutor online systems, for instance, private class, virtual classroom, online exam, etc. RuangGuru is in cooperation with 32 out of 34 provinces in Indonesia to support online learning. 15 million students have experienced to use RuangGuru.

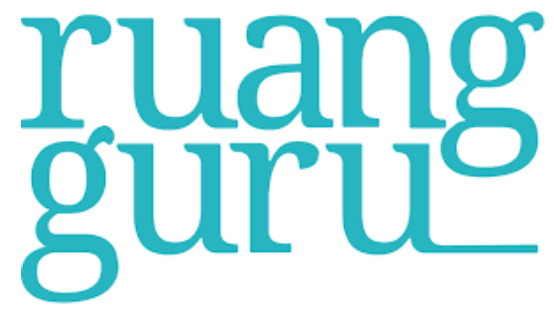

\section{Figure 5Ruang Guru Logo \\ Source:https://RuangGuru.com/general/about}

Questions raised through unit analysis are examined by qualitative content analysis in online media. The author's implications are based on adequate literary quotations, can form a glossary, or comprise footnotes. In the first step, the lexico-grammatical resolution is traced from the use or choice of vocabulary (lexicon) and structuring of the language used (grammatical). Both of these things have been determined, then exploration material is determined followed by boundary analysis and broad context analysis.

Structure following procedures is used in classical content analysis which is often seen as the most crucial content analysis technique. The goal is to filter out certain structures of material because texts are generally structured according to specific contents, shapes, and scales. The first stage is the determination of the unit of analysis, after which the dimension of structuring will be formed based on a theoretical framework as the basis for a predefined data categorization system. This research uses Ideation theory to describe the news..

\section{DISCUSSION}

There are two articles from e-newspapers related to education in times of Covid-19. The e-newspapers which the authors would like to analyze are NewIndianExpress.com and JakartaGlobe.id. The authors would like to compare and find the similarities between those two articles. The authors also relate the ideation theory with the Mayring method to find the same ideas or brainstorming on those two articles. The two news is divided into three parts which have different categories of ideation which are cognitive, emotional, and social. The two news are listed below (figure 6 and figure 7).

The abstraction process can be seen in the news when the government made policies to dismiss all students affected, this situation is used by various learning service providers through the online application to the selling point of the product. So that online learning has the value of substitution in the process of conventional learning towards online learning.

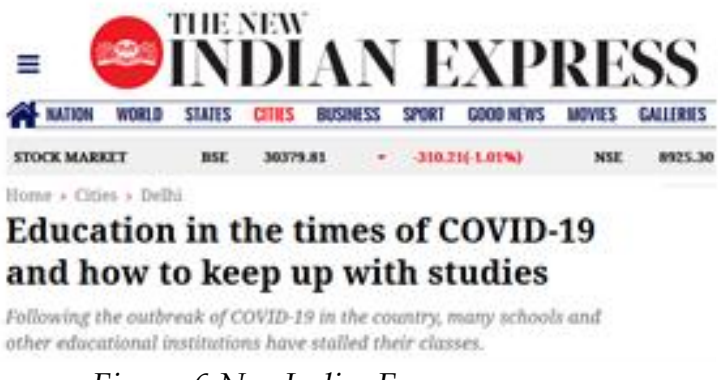

Figure 6 NewIndianExpress.com

The newsindianexpress.com news quote shows that the government has the same beliefs, values, perceived risks, and subjective norms that prevent COVID-19. Prime Minister Narendra Modi spoke to the public on March 19 to maintain social distance and provide online education for students who are required to stay at home. The value of trust between the government and various online learning service providers is also conveyed to assist students in using a good platform. It was written that responding from various platforms also supported positively as did the British Council language learning institutions.

"Following the outbreak of COVID-19 in the country, many schools and other educational institutions have stalled their classes. Even before Prime Minister Narendra Modi addressed the nation on March 19 to maintain social distancing, a lot of students had already confined themselves to their homes..." (Source: NewIndianExpress.com)

The online media of jakartaglobe.id writes about the decisiveness of several local governments in Indonesia. One of them is the 
Bogor city government, represented by Fahkrudin as head of the education service, urging people to stay at home to reduce the spread of COVID-19. In this case, Modi and Fahkrudin have actions against subjective norms that give them direction to order their people to remain at home.

Fahkrudin, the head of Bogor's education department, said at the moment the city faced difficulty with providing adequate face masks and antiseptic liquid for the schools. "Prevention protocols dictate we must provide protective equipment at the schools. But this time, it is still difficult to obtain," Fahkrudin said. (Source JakartaGlobe.id)

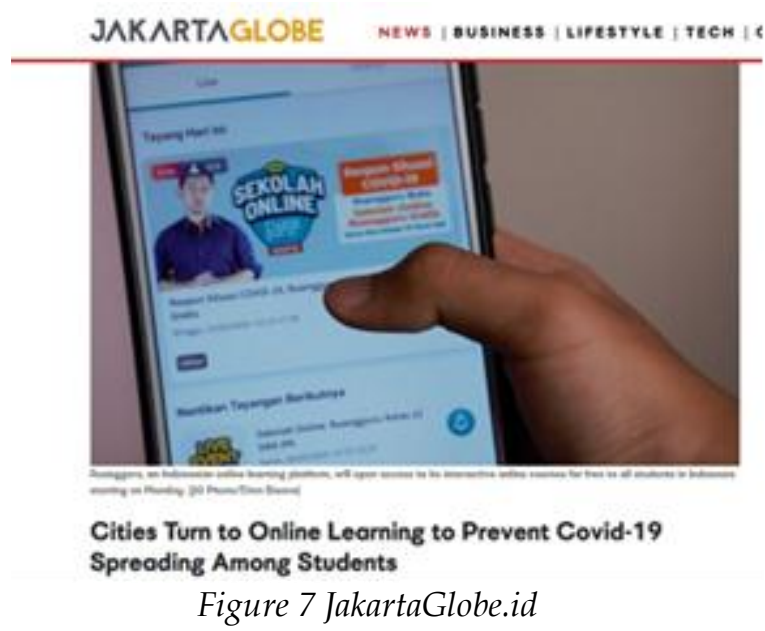

The news on newindianexpress.com and jakartaglobe.id shows the emphasis on subjective norms on society. Subjective norms are a belief which most of the people will approve of someone's decision. The belief is determined by social pressure, thus, all individuals will act in the same actions or certain manner (Ham et al., 2016). As their subjective norms relate to the social pressure which they have made decisions to reduce perceived risks, thus, the belief and the decisions which they make are the best solutions for all.

The content application in the news newindianexpress.com and jakartaglobe.id is seen in the presence of Vedantu and RuangGuru application as a representation amidst various start-ups in the globalization era, which were initially used as an alternative, means to support learning but succeeded in increasing confidence to take the government to assist in the education sector during the pandemic COVID-19. Belief means acceptance of someone's decision or how we apprehend and discuss the reality that can be traced through the historical development of academic discourse (Motz, 2014). In this situation, Modi and Fahkrudin believe their people will accept their decisions or policy to limit activities outside included school activity.

Lastly, it comes out with a certain value that the decision that Modi and Fahkrudin have decided is important and it is the way to act in this situation of Pandemic COVID-19. Eventually, it converts to a self-image that Modi and Fahkrudin have the ability to lead their people against COVID-19. Amid social distancing policy, Narendra Modi and Fahkrudin still give a good solution in education problems where they provide Vedantu and RuangGuru as tools to learn online. Amid social distancing policies, Modi and Fahkrudin still provide good solutions to educational problems where they provide Vedantu and RuangGuru as a tool for online learning.

"The spread of COVID-19 has forced many educational institutions across the globe to close campuses. India has over 37 million students enrolled in higher education. An interruption in the delivery of education could cause long term disruption. Thepandemic requires universities to rapidly offer online learning to their students..." says Raghav Gupta, Managing Director (India and APAC), Coursera." (Source: NewIndianExpress.com)

The Emotional Concept in Ideation explains how emotions can be responded to and so becomes empathy. The Newsindianexpress.com framing takes a perspective on the ability of Indian universities to use technology. So that technology, in this case, can improve the quality of empathy of policyholders in making quick decisions during the COVID19 pandemic. This reinforces McLuhan's idea of the Global Village concept of how humans are encouraged to be able to connect fully in the digital age so that it becomes a challenge for other countries that are not yet capable of developing to move quickly. 
"In West Java, Indonesia's most populous province with 49 million people, students would also study at home for two weeks, Governor Ridwan Kamil said on Sunday. "Students will be able to receive instruction from their teacher remotely using an online system," Ridwan said... Meanwhile, Central Java Governor Ganjar Pranowo said on Saturday that the province suspended teaching activities at all levels of educations, except for those who would be facing the final exam next week. "Those who are not taking exams, will not go to schools and should take an online course," Ganjar said. (Source: JakartaGlobe.id)

Indonesia as a broad country is a challenge where decisions must be centralized responded with various regional studies (Fernando et al, 2019). So the empathy produced depends on each regional head. The media of jakartaglobe.id provides a different perspective by raising several provinces with an indication of the spread of the highest cases. The Governor of Banten, West Java, and East Java have the same empathy to stop all offline educational activities and go online by promoting humanity even though on one side of education technology is inadequate.

Framing the media in India and Indonesia, explained the figure of leadership has similar efficacy in which they believe students can still study at home with online education. Meanwhile, it creates an emotional response, since, some schools' online system is not ready for this situation in India (Banchariya Sheetal And, 2020) even so in Indonesia (Angdhiri, 2020). Governments have to make quick decisions through this outbreak since the virus is rapidly spreading. As a result, not all decisions can be applied, ideally. During the outbreak, there is ideation back and forth which is related to the emotional category where self-efficacy and emotional response is being created.

Social concepts talk about support and influence, and the ability to carry out personal advocacy. The rapid reaction issued by online learning service providers actually helped the government through quick decisions made regarding several schools not ready to do so. Vedantu, as an online learning application provides free online schooling during the COVID-19 pandemic in India (Editor, 2020a). The news of newindianexpress.com covers the whole statement of Vanmsi Krisha as CEO of the Vedantu application which supports and collaborates with the Indian state to provide online guidance during the pandemic.

"We also support and cooperate with state and national government authorities to put all necessary measures in place to ensure the continued well-being of all... "At Vedantu, we believe that the best quality of education should be accessible to everyone, anytime. We believe online learning is a safe option in these risky and uncertain times. The students can study from the safety of their home and avoid travel to public places. We are closely monitoring the impact of COVID-19 and are here to assist students and schools with all their learning needs." (Source: NewIndianExpress.com)

In this situation, Vedantu and RuangGuru have given support and influence to society. Where online learning before COVID-19 was only alternation or secondary method, now, it becomes the main method where it can help to prevent the spread of pandemic COVID-19. The news on jakartaglobe.id also frames the RuangGuru appellation which shows support and advocacy that provides free online classes. RuangGuru supports the majority of users to provide free internet access, in collaboration with one of the largest telecommunications providers in Indonesia, Telkomsel (Fach, 2020).

"RuangGuru, an Indonesian online learning platform, announced on Saturday that it would open access to its interactive online courses for free to all students in Indonesia. Starting on Monday, the live course sessions would be available from 08:00 a.m. to 12:00 p.m. every day, said Belva Devara, RuangGuru's co-founder and chief executive in a video announcement." (Source: JakartaGlobe)"

The Pandemic COVID-19 has risen ideations in education. Through governments' decision to close schools the government tries to replace the offline class into an online class. However, there are problems through the limitations of technology or tools. Fortunately, Vedantu and RuangGuru as educational 
platforms provide free online classes amid the outbreak. They support the government to keep students in India and Indonesia learning in times of COVID-19. In a time of the pandemic, technologies have empowered citizens to form transportation for advancing concern where this situation linked to human rights, ecology, and development (Narula, 2012). Moreover, Vedantu and Ruangguru are technology that is easy to use. It would lead to an era where people are more knowledgeable and to improve all decisions (Kabha et al., 2019).

\section{CONCLUSION}

Governments' temporary policies in India and Indonesia such as social distancing and close schools' activities create many ideations as a theory in this journal. The theory explains how cognitive and emotional are involved in creating ideations. Cognitively, the governments give policies to prevent the spread, however, in case of schools' activities being stopped its emotional factor is not supported by the system in India neither in Indonesia, but Vedantu and RuangGuru support to provide online learning in a time of COVID-19. It implies that technology can help society when they are restricted to do activities outside in the time of Pandemic. Companies could see this as references how they should develop their companies where absolutely technology is needed to support the companies at any time, they need it.

\section{ACKNOWLEDGMENT}

We are grateful because we managed to complete this journal within time. This journal cannot be completed without the effort and cooperation of our group members' in this journal. Moreover, we would like to thank NewIndianExpress.com and JakartaGlobe.id through the news which we read, also, this journal researches many encouragements been given as this country can run its education excellence even in time of Pandemic COVID19. We also sincerely thank the Ministry of Research and Technology / National Agency for Research and Innovation of the Republic of Indonesia number 054 / LL3 / AM / 2020, March 23, 2020, who fully supports us in the grant program, so that this research paper can proceed.

\section{REFERENCES}

Angdhiri, R. P. (2020). Challenges of Home
Learning During A Pandemic Through The Eyes Of A Student.

Asquith, J. (2020). [Global Update] Complete Coronavirus Travel Guide - The Latest Countries Restricting Travel.

Assarroudi, A., Heshmati Nabavi, F., Armat, M. R., Ebadi, A., \& Vaismoradi, M. (2018). Directed qualitative content analysis: the description and elaboration of its underpinning methods and data analysis process. Journal of Research in Nursing, 23(1), 42-55.

https://doi.org/10.1177/1744987117741667

Babalola, S., Folda, L., \& Babayaro, H. (2016). The Effects of a Communication Ideation and Use in Northern Program Among Nigeria on Contraceptive Women Young. Studies in Family Planning, 39(3), 211-220.

Banchariya Sheetal And, S. M. (2020). Why Online Learning Is Not For Everyone.

Briggs, R. O., \& Reinig, B. A. (2007). Bounded Ideation Theory: A New Model of the Relationship Between Idea- quantity and Ideaquality during Ideation. Journal of Management Information Systems, 27, 1-10.

Editor. (2020a). COVID-19 Impact Vedantu to Provide Free Access to Live Classes, Study Material, Tests, Assignments - The Hindu BusinessLine.

Editor. (2020b). JakartaGlobe.Id.

Editor. (2020c). Education In The Times of COVID-19 And How To Keep Up With StudiesThe New Indian Express.

Editor. (2020d). Schools, colleges shut till March 31 in Kolkata.

Fach, R. (2020). COVID-19 Tech Startups Offer Free Services To Students, Employees In SelfQuarantine - Science \& Tech.

Fernando, J., Sya, M., \& Marta, R. F. (2019). Amalgamation as a Strengthening Ethic. MIMBAR : Jurnal Sosial Dan Pembangunan, 35(2), 334-341. https://doi.org/10.29313/mimbar.v35i2.4863

Fong, T. L., \& Nyathi, S. E. C. (2019). Gender Representation and Framing of Malaysian Women: A Study of Feature Articles in Female Magazine. Journal of Content, Community and Communication, 10(9), 29-38. https://doi.org/10.31620/jccc.12.19/04

Forster, P. W., \& Tang, Y. (2005). The role of 
online shopping and fulfillment in the Hong Kong SARS crisis. Proceedings of the Annual Hawaii International Conference on System Sciences, $\quad 00(\mathrm{C}), \quad 271$. https://doi.org/10.1109/hicss.2005.615

Fung, I. C. H., Tse, Z. T. H., \& Fu, K. W. (2015). The use of social media in public health surveillance. Western Pacific Surveillance and Response Journal :: WPSAR, 6(2), 3-6. https://doi.org/10.5365/WPSAR.2015.6.1.019

Gode, H. E. (2019). Employee Ideation on Internal Social Media : Addressing Uncertainty through Dialogue Strategies Employee Ideation on Internal Social Media : Addressing Uncertainty through Dialogue Strategies. International Journal of Strategic Communication, 00(00), 1-19. https://doi.org/10.1080/1553118X.2019.16544 81

Govender, N. (2014). Magazines Representation of Women and Its Influence on Identity Construction: A South African Perspective. Mediterranean Journal of Social Sciences, 5(20), 2278-2283. https://doi.org/10.5901/mjss.2014.v5n20p227 8

Ham, M., Jeger, M., \& Ivković, A. F. (2016). The Role of Subjective Norms in Forming the Intention to Purchase Green Food. Economic Research-Ekonomska Istraživanja ISSN:, 28(February).

https://doi.org/10.1080/1331677X.2015.10838 75

Hay, L., Duffy, A. H. B., Grealy, M., Tahsiri, M., Mcteague, C., Vuletic, T., Duffy, A. H. B., Grealy, M., Tahsiri, M., Mcteague, C., \& Vuletic, T. (2019). A Novel Systematic Approach For Analysing Exploratory Design Ideation. Journal of Engineering Design, 0(0), 123.

https://doi.org/10.1080/09544828.2019.16623 81

Kabha, R., Kamel, A., Elbahi, M., \& Narula, S. (2019). Comparison Study between the UAE, the UK, and India in Dealing with WhatsApp Fake News. Journal of Content, Community and Communication, 10, 176-186. https://doi.org/10.31620/JCCC.12.19/18

Khiang, C. C., Ahmad, F., Ibrahim, F., \& Kee, C. P. (2012). Investigating News Framing: A Comparative Study Of Media Coverage On Contemporary Education Issues - Menyiasat
Framing Berita: Kajian Perbandinagan Liputan Media Isu - Isu Pendidikan Kontemporari. Jurnal Komunikasi Malaysian Journal of Communication, 28(1), 17-31.

Kholik, D. I. (2015). Bingkai Berita Media Indonesia Tentang Terpilihnya Susilo Bambang Yudhoyono Sebagai Ketua Umum Partai Demokrat. Bricolage : Jurnal Magister Ilmu Komunikasi, 02.

Kincaid, D. L. (2015). Mass Media, Ideation, And Behavior; A Longitudinal Analysis Of Contraceptive Change In The Philippines. Communication Research, 27.

Li, Q., Zhou, L., Zhou, M., Chen, Z., Li, F., Wu, H., Xiang, N., Chen, E., Tang, F., Wang, D., Meng, L., Hong, Z., Tu, W., Cao, Y., Li, L., Ding, F., Liu, B., Wang, M., Xie, R., ... Feng, Z. (2014). Epidemiology of human infections with avian influenza $\mathrm{A}(\mathrm{H} 7 \mathrm{~N} 9)$ virus in China. New England Journal of Medicine, 370(6), 520-532. https://doi.org/10.1056/NEJMoa1304617

Marta, R. F., Fernando, J., \& Simanjuntak, R. F. (2019). Eksplikasi Kualitas Konten Peran Keluarga Pada Instagram @Kemenpppa. ETTISAL : Journal of Communication, 4(2), 137. https://doi.org/10.21111/ejoc.v4i2.3702

Marta, R. F., \& Rieuwpassa, J. S. (2018). Identifikasi Nilai Kemajemukan Indonesia sebagai Identitas Bangsa dalam Iklan Mixagrip Versi Keragaman Budaya. Jurnal Kajian Komunikasi, 6(1), 37-50.

Motz, M. (2014). The Practice of Belief. American Folklore Society, 111(441), 339-355.

Mustaffa, N., \& Ibrahim, F. (2018). Visual Framing of Lahad Datu Crisis News. Jurnal Komunikasi Malaysian Journal of Communication, 34(1), 170-184.

Narula, S. (2012). Mass Communication \& Journalism Models of Structuring Peace and Gandhi in Modern Democratic System. Journal of Mass Communication \& Journalism, 2(5), 5-7. https://doi.org/10.4172/2165-7912.1000e117

Nugroho, G. A. A. A. R. (2020). Regions Close Schools, Cancel Public Events Because of COVID19 - National - The Jakarta Post.

Priyo Sadono, T., \& Fensi, F. (2015). Pemberitaan Bergabungnya Hary Tanoesoedibjo Ke Partai Hanura (Analisis Ekonomi Politik Media Dalam Framing Portal Online Okezone.com dan Metrotvnews.com). Bricolage : Jurnal Magister Ilmu Komunikasi, 01, 
$1-28$.

Qiu, W., Rutherford, S., Mao, A., \& Chu, C. (2017). The Pandemic and its Impacts. Health, Culture and Society, 9, 1-11. https://doi.org/10.5195/hcs.2017.221

Rgovic, V., Alton, W., \& Hulkin, S. (2013). Improving Open Innovation: $\mathrm{C}$ hallenges For Managing Communication And Creative Ideation. Daaam International Scientific Book 2013, 921-940. https://doi.org/10.2507/daaam.scibook.2013. 57

Sachdeva, P., \& Tripathi, D. (2019). A Critical Education for 21st Century: A Study on Youth and Media literacy. Journal of Content, Community and Communication, 10(9). https://doi.org/10.31620/jccc.12.19/07

Satriani, A. (2018). Framing Analysis of News
Article about Clashes between Police and Terrorist Prisoners in Indonesia Publishing by ABC.net.au and SBS.com. Mediator: Jurnal Komunikasi, 11(2), 248-255. https://doi.org/10.29313/mediator.v11i2.3947

Schinkel, A., Ruyter, D. J. D. E., \& Aviram, A. (2015). Education and Life' s Meaning. Journal of Philosophy of Education, $00(0)$.

Schwartz, M., Gupta, S. K., Anand, D. K., \& Kavetsky, R. (2007). Virtual Mentor. American Medical Association Journal of Ethics, 12(9), 280287. https://doi.org/10.1145/1660877.1660918

Singh, P. (2019). New Media as a Change Agent of Indian Television and Cinema: A study of over the top Platforms. Journal of Content, Community and Communication, 9(2019), 131-137. https://doi.org/10.31620/JCCC.06.19/18 